\title{
Isolation of Mycobacterium avium and other nontuberculous mycobacteria in chickens and captive birds in peninsular Malaysia
}

\author{
Abdul Sattar ${ }^{1,2+}$, Zunita Zakariaa, ${ }^{2,3^{*}} \mathbb{D}$, Jalila $\mathrm{Abu}^{4 \dagger}$, Saleha A. Aziz ${ }^{2 \dagger}$ and Gabriel Rojas-Ponce ${ }^{5+}$
}

\begin{abstract}
Background: Mycobacterium avium complex (MAC) causes a chronic infectious in the birds known as avian mycobacteriosis. Almost all species of the birds are susceptible to MAC which consists of two closely related species of mycobacteria, that is, M. avium and M. intracellulare. This study aimed to determine the occurrence of Mycobacterium avium subsp. avium (MAA) in chickens and captive birds in selected states of Peninsular Malaysia.

Results: A 300 fecal samples were collected from village chickens $(n=100)$, layer chickens $(n=100)$ and captive birds $(n=100)$. Fecal samples were split into two aliquots for microbiological and molecular detection of MAA. Microbiology detection consisted of microscopy (Ziehl-Neelsen staining) and culture of samples decontaminated with 1\% Cetylperidinium chloride and vancomycin, nalidixic acid and amphotericin B (VNA) antibiotic cocktail [vancomycin (VAN) $100 \mu \mathrm{g} / \mathrm{ml}$, nalidixic acid (NAL) $100 \mu \mathrm{g} / \mathrm{ml}$ and amphotericin B (AMB) $50 \mu \mathrm{g} / \mathrm{ml}$ ] onto Löwenstein-Jensen (L-J). Molecular detection (PCR-IS901) was performed to detect MAA DNA from the feces and PCR-16S rRNA and IS901 for identification of genus Mycobacterium and Mycobacterium avium sub species avium isolated onto L-J. All samples (296) were AFB negative smear. M. avium was isolated in $0.3 \%(1 / 296)$ samples by culture and detected in 2.5\% (6/242) samples by PCR (IS901). Other mycobacteria were found in 1.7\% (5/296) chickens. Of five isolates, two were identified as Mycobacterium terrae and $M$. engbaekii and remaining isolates were not sequenced. Birds positive for M. avium included White Pelican $(n=1)$ Black Hornbill $(n=1)$, Macaw $(n=2)$, Cockatoo $(n=2)$ and village chicken $(n=1)$.

Conclusion: It is concluded that chickens and birds were infected with $M$. avium in selected areas of Peninsular Malaysia. Although, PCR is rapid, reliable and cost effective method for detection of M. avium in a subclinical stage, the culture of the avian feces should still be used as a reference test for the diagnosis of avian tuberculosis.
\end{abstract}

Keywords: Avian tuberculosis, Mycobacterium avium subsp. avium, Culture, Löwenstein Jensen, Cetylperidinium chloride, PCR, IS901, Peninsular Malaysia

\footnotetext{
* Correspondence: zunita@upm.edu.my

†Abdul Sattar, Zunita Zakaria, Jalila Abu, Saleha A. Aziz and Gabriel Rojas-

Ponce contributed equally to this work.

${ }^{2}$ Department of Pathology and Microbiology, Faculty of Veterinary Medicine,

Universiti Putra Malaysia UPM, 43400 Serdang, Selangor, Malaysia

${ }^{3}$ Institute of Bioscience, Universiti Putra Malaysia, 43400-UPM, Serdang,

Selangor, Malaysia

Full list of author information is available at the end of the article
}

C C The Author(s). 2020 Open Access This article is licensed under a Creative Commons Attribution 4.0 International License, which permits use, sharing, adaptation, distribution and reproduction in any medium or format, as long as you give appropriate credit to the original author(s) and the source, provide a link to the Creative Commons licence, and indicate if changes were made. The images or other third party material in this article are included in the article's Creative Commons licence, unless indicated otherwise in a credit line to the material. If material is not included in the article's Creative Commons licence and your intended use is not permitted by statutory regulation or exceeds the permitted use, you will need to obtain permission directly from the copyright holder. To view a copy of this licence, visit http://creativecommons.org/licenses/by/4.0/ The Creative Commons Public Domain Dedication waiver (http://creativecommons.org/publicdomain/zero/1.0/) applies to the data made available in this article, unless otherwise stated in a credit line to the data. 


\section{Background}

Mycobacterium avium complex (MAC) is an opportunistic pathogen and ubiquitous in the environment that cause tuberculosis in the birds [1,2]. Avian tuberculosis causes irreparable losses to rare and endangered avian species such as wild birds, captive pet birds and domestic hen [2, 3]. Age, congested population of birds and unhygienic conditions are considered the major predisposing factors [4]. Modern poultry husbandry practices have significantly reduced the incidence of tuberculosis in commercial poultry [2, 3]. However, sporadic outbreaks have been reported in commercial chicken and duck flocks at different times [1, 5].

Poultry meat is the major source of the cheap protein to the multi ethnic population in Malaysia [6]. The total poultry population in Peninsular Malaysia was estimated to be $161.3 \mathrm{~m}$ broiler, $56.7 \mathrm{~m}$ layer, $17.8 \mathrm{~m}$ breeder, 12.8 $\mathrm{m}$ local chicken and $9.6 \mathrm{~m}$ ducks [7]. The share of indigenous chickens and ducks in the poultry population is estimated as 5.1 and $1.15 \%$ respectively [7]. Large proportion of villagers in Peninsular Malaysia is involved in raising indigenous chicken [8]. Despite that village based poultry plays a significant role in improving the nutritional status, income, food security and livelihood of many small holders [9], some infectious diseases such as Avian influenza, Newcastle disease, infectious bursal disease and salmonellosis are the major cause of high mortality and low production of the poultry from different part of the world and Malaysia [10-13]. Although, avian tuberculosis is also another important infectious diseases that has been reported from different poultry in the world [1, 14-16], there is no published data about the prevalence of this infectious disease neither in poultry nor in captive birds from Malaysia.

Diagnosis of avian tuberculosis can be made by histopathology, light microscopy and isolation at postmortem [17] and from live birds by using feces as noninvasive source [18]. Light microscopy is the cheapest and rapid method to detect mycobacteria, but it has very low sensitivity [19]. Isolation of mycobacteria on culture media is the gold standard $[19,20]$, however, the main drawback of culture is its low sensitivity. Sensitivity of culture depends on the number of organism present in the samples [20]. Liquid media are preferred over conventional egg based solid media such as Löwenstein-Jensen (L-J) due to rapid detection [21]. However, high cost of the liquid media has limited their routine use [19]. L-J culture is cost effective and is frequently used for culture in low resource settings [19]. L-J recovers more positive cultures and more colonies on positive samples than L-J modified with antibiotics and Herald's egg yolk medium [22]. Additionally, sensitivity of primary culture for mycobacteria can be improved when a gentle chemical agent is used to kill unwanted bacteria present in the specimen [23]. Studies have shown that the Cetylperidinium chloride - Sodium chloride (CPC) method is favorable alternative method to isolate mycobacteria [24, $25]$ as it is less toxic to mycobacteria [24, 25], more effective in controlling culture contamination [23, 24], supports early growth of mycobacteria $[23,26]$ and does not need neutralization as its inhibitory effects are neutralized on egg based media [27]. Likewise, the incorporation of a VNA antibiotic cocktail composed by vancomycin (VAN), nalidixic acid (NAL) and amphotericin (AMB), in the decontamination of sample has improved the sensitivity of the primary culture (CPC $27.8 \%$ and CPC-VAN 66.7\%) and reduced the contamination of cultures (CPC 66.7\% \% and CPC-VAN 19\%) [24]. Polymerase chain reaction (PCR) is reasonable alternative to conventional methods for the detection of slow growing mycobacteria [28]. PCR is rapid, reliable, less laborious, and cost effective [29]. Previous studies have shown that PCR targeting IS901 gene detects most of the pathogenic mycobacteria [30]. PCR is more sensitive than culture to detect mycobacteria in the samples containing low number of mycobacteria [14]. Kriz and coworkers (14) detected $M$. avium sub species avium and M. avium from tissue samples of cochin hen using quantitative real time PCR by amplification of genes IS901 and IS1245.

In order to determine the presence of avium tuberculosis in birds, this study reported the occurrence of $M$. avium subsp. avium (MAA) in chickens and captive birds from selected states of Peninsular Malaysia by isolating MAA from avian fecal samples on L-J culture and by direct polymerase chain reaction (PCR) by amplifying insertion sequence IS901 [14, 31].

\section{Results}

\section{Isolation of mycobacteria}

Of 300 fecal samples, 296 samples (888 replicates) were cultured and 4 samples were excluded from culture because of the small quantity of feces and were used only for PCR detection (Table 1). Distribution of 296 fecal samples used for culture was as village chickens (Gallus domesticus) (100), layer chickens (100) and captive birds (96). Six (6) L-J cultures (6/296, 2\%) were AFB-positive. Colonies were seen within two to three weeks of incubation. Of six (6) AFB positive isolates, five (5) were identified as mycobacteria by PCR $16 \mathrm{~S}$ rRNA (Fig. 1) and remaining one AFB isolate was not amplified due to insufficient colonies. Further amplification of five (5) mycobacterial isolates by PCR IS901, only one isolate was amplified as M. avium subsp. avium (Fig. 2) which was further confirmed by sequencing. This isolate came from a white pelican (Pelicanus onocrotalus). Two amplicons of PCR 16S-rRNA were sequenced and identified as Mycobacterium terrae and Mycobacterium 
Table 1 Occurrence of Mycobacterium avium in chickens and birds in selected area of Peninsular Malaysia

\begin{tabular}{|c|c|c|c|c|c|c|c|c|c|c|}
\hline \multirow{2}{*}{$\begin{array}{l}\text { Farm } \\
\text { ID }\end{array}$} & \multirow{2}{*}{$\begin{array}{l}\text { Total } \\
\text { samples } \\
(n)\end{array}$} & \multicolumn{6}{|c|}{ Culture on L-J } & \multicolumn{3}{|c|}{ Direct PCR (IS901) } \\
\hline & & $\begin{array}{l}\text { - Samples } \\
\text { for culture } \\
(n)\end{array}$ & $\begin{array}{l}\text { Replicates } \\
\text { (n) }\end{array}$ & $\begin{array}{l}\text { Culture } \\
\text { positive } \\
(\%)\end{array}$ & $\begin{array}{l}\text { Identification } \\
\text { of isolates }\end{array}$ & $\begin{array}{l}\text { Contaminated } \\
\text { cultures } \\
\text { (replicate \%) }\end{array}$ & $\begin{array}{l}\text { Species of } \\
\text { birds }\end{array}$ & $\begin{array}{l}\text { Samples } \\
\text { for PCR } \\
(n)\end{array}$ & $\begin{array}{l}\text { Positive } \\
\text { (\%) }\end{array}$ & Species of birds \\
\hline $\mathrm{F} 1^{*}$ & 4 & 4 & 12 & 0 & & $33.3 \%$ & & 4 & 0 & \\
\hline$F 2^{*}$ & 29 & 29 & 87 & so & & $0 \%$ & & 8 & 0 & \\
\hline $\mathrm{F}^{*}$ & 12 & 12 & 36 & 0 & & $5.6 \%$ & & 5 & 0 & \\
\hline $\mathrm{F} 4^{*}$ & 12 & 12 & 36 & 0 & & $100 \%$ & & 11 & $1(9.0)$ & Gallus domesticus \\
\hline $\mathrm{F}^{*}$ & 23 & 23 & 69 & 0 & & $14.5 \%$ & & 16 & 0 & \\
\hline$F 6^{*}$ & 4 & 4 & 12 & $2(50)$ & $\begin{array}{l}\text { M. terrae, M. } \\
\text { engbaekii }\end{array}$ & $66.7 \%$ & $\begin{array}{l}\text { Gallus } \\
\text { domesticus }\end{array}$ & 4 & 0 & \\
\hline $\mathrm{F}^{*}$ & 16 & 16 & 48 & $2(12.5)$ & $\begin{array}{l}\text { Mycobacterium } \\
\text { spp. }(2 \text { isolates })^{a}\end{array}$ & $45.8 \%$ & $\begin{array}{l}\text { Gallus } \\
\text { domesticus }\end{array}$ & 10 & 0 & \\
\hline $\mathrm{F}^{\#}$ & 11 & 11 & 33 & 0 & & $69.7 \%$ & & 11 & 0 & \\
\hline $\mathrm{Fg}^{\#}$ & 11 & 11 & 33 & 0 & & $57.6 \%$ & & 11 & 0 & \\
\hline $\mathrm{F} 10^{\#}$ & 35 & 35 & 105 & 0 & & $30.5 \%$ & & 35 & 0 & \\
\hline $\mathrm{F} 11^{\#}$ & 43 & 43 & 129 & 0 & & $23.3 \%$ & & 43 & 0 & \\
\hline $\mathrm{F} 12^{x}$ & 5 & 5 & 15 & $1(20)$ & M. avium & $20.0 \%$ & $\begin{array}{l}\text { Pelecanus } \\
\text { onocrotalus }\end{array}$ & 2 & 0 & \\
\hline $\mathrm{F} 13^{*}$ & 12 & 12 & 36 & 0 & & $11.1 \%$ & & 11 & $2(18.2)$ & $\begin{array}{l}\text { Ara spp. and } \\
\text { Cacatua spp. }\end{array}$ \\
\hline $\mathrm{F} 14^{x}$ & 15 & 15 & 45 & 0 & & $33.3 \%$ & & 11 & $2(20)$ & $\begin{array}{l}\text { Ara spp. and } \\
\text { Anthracoceros } \\
\text { malayanus }\end{array}$ \\
\hline $\mathrm{F} 15^{x}$ & 21 & 20 & 60 & 0 & & $1.7 \%$ & & 21 & $1(4.7)$ & Cacatua spp. \\
\hline$F 16^{x}$ & 8 & 8 & 24 & 0 & & $0 \%$ & & 0 & 0 & \\
\hline $\mathrm{F} 17^{x^{*}}$ & 3 & 2 & 6 & 0 & & $33.3 \%$ & & 3 & 0 & \\
\hline$F 18^{x}$ & 11 & 11 & 33 & 0 & & $30.3 \%$ & & 11 & 0 & \\
\hline$F 19^{x}$ & 25 & 23 & 69 & $1(4,3)$ & $\begin{array}{l}\text { Mycobacterium } \\
\text { spp. (1) }\end{array}$ & $21.7 \%$ & $\begin{array}{l}\text { Phigys } \\
\text { solitaries }\end{array}$ & 25 & 0 & \\
\hline Total & 300 & 296 & 888 & $6(2.0)$ & & 248/888 (27.9\%) & & 242 & $6(2.5)$ & \\
\hline
\end{tabular}

*Village chickens, "Layer chickens and * captive exotic birds. No correlation was seen among the positive samples by culture and direct PCR. PCR was specific to M. avium (IS901). $\bullet$ Z-N stain of all concentrated avian fecal samples were negative. ${ }^{a}$ sequencing was not performed for these isolates. ${ }^{b}$ this isolate was positive for Z-N staining and PCR was not performed

engbaekii (Table 1). Sequencing was not performed for remaining two isolates because both isolates did not encode for IS901 sequence, meant that both isolates did not belong to MAA. No mycobacteria were isolated from layer chickens (Table 1). The partial sequences can be accessed at NCBI using the accession numbers MH428008 (Mycobacterium avium), MH333265 Mycobacterium terrae (Mycolicibacter terrae) and MH333264 Mycobacterium engbaekii (Mycolicibacter engbaekii).

\section{Contamination of cultures}

Overall proportion of contamination was 27.9\% (248/ 888 replicates) (Table 1). Proportion of culture contamination was 35.3\% (106/300), 34.7\% (104/300) and 13.1\% (38/288) for village chicken (F1 to F7), layer chicken (F8 to F11), and exotic captive birds (F12 to F19), respectively. Contamination of primary cultures appeared as mucoid white or yellow creamy colonies causing blue discoloration and liquefaction of L-J green slants. Contaminating colonies covered the surface of the L-J slant and most of them grown during first week of incubation. Fungal contamination appeared after 4th week of incubation. Identification of contaminating organisms was not performed as it was beyond the scope of this study.

\section{Detection of Mycobacterium avium DNA from fecal samples}

Two hundred and forty two (242) out of 300 fecal samples were processed by PCR (Table 1). Remaining 58 samples were excluded from PCR detection because 20 fecal samples were only enough for culture and DNA extraction from 38 samples was not successful (no visible DNA yield in the agarose electrophoresis) perhaps due to technical issues like poor lysis ability of QIAamp ${ }^{\circ}$ Fast 


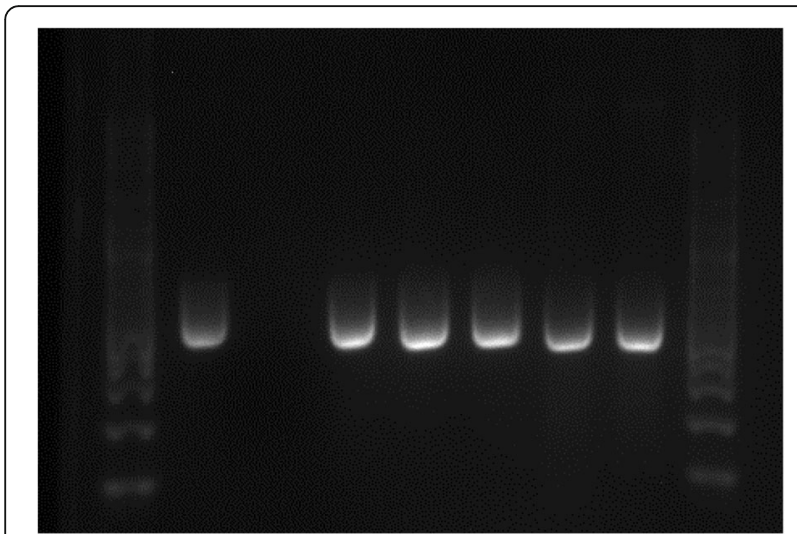

Fig. 1 Agarose electrophoresis of PCR (16S rRNA) product of mycobacteria isolated from feces. $\mathrm{M}, 100 \mathrm{bp}$ size molecular DNA marker; C+ positive control; C- negative control; 1 to 5 (bp-564) isolates

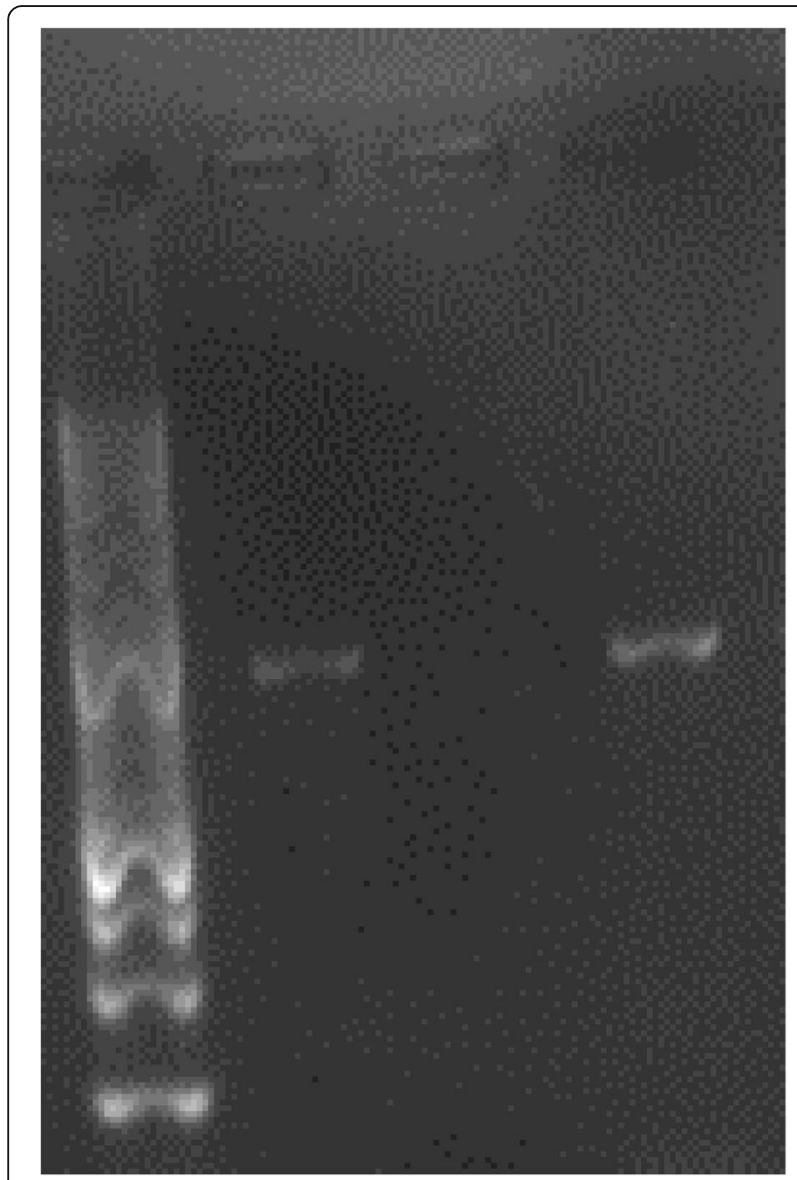

Fig. 2 Agarose electrophoresis of PCR (IS901) product of Mycobacterium avium isolated from Pelicanus onocratalus' feces. Other negative IS901 samples are not shown on the gel. M, 100 bp size molecular DNA marker; C+ positive control; C- negative control; 1 (bp-753)
DNA Stool Mini Kit (Qiagen ${ }^{\circ}$ ) and 5 min incubation of feces InhibitEX homogenate on heating block. Distribution of the samples was; village chicken $(n=58)$, layer chicken $(n=100)$ and exotic captive birds $(n=84)$ (Table 1). PCR (IS901) detected $753 \mathrm{bp}$ fragment of IS901 of M. avium in $2.5 \%(6 / 242)$ birds (Figs. 3 \& 4). Proportion of the positive exotic captive birds and village chickens were $5.9 \%(5 / 84)$ and $1.7 \%$ (1/58) respectively (Fig. 5). No M. avium was detected in the layer chickens (Fig. 5). PCR positive birds included Macaw Ara spp. $(n=2)$, Cockatoo Cacatua spp. $(n=2)$, Black Hornbill Anthracoceros malayanus $(n=1)$ and village chicken Gallus domesticus $(n=1)$ (Table 1).

\section{Risk factor analysis}

Risk factors analysis was performed for those flock size which showed positive samples. Univariate analysis of the risk factors revealed that flock size $<50$ versus $>500$ $(\mathrm{OR}=11.47 P=0.01 \mathrm{Cl}: 1.31-100.3)$ and breed of the birds (local chickens verses exotic captive birds) ( $\mathrm{OR}=$ $0.103 ; P=0.02$; Cl: $0.012-0.89$ ) were significant predictors of M. avium occurrence in the birds (Table 2). Although feed [32], water [31] and free birds [33] are considered main reservoirs of MAA, in this study, feed $(P=0.07)$, source of water $(P=0.09)$ and access of free birds were not statistically significant risk factors.

\section{Sequence analysis}

BLAST analysis of two sequences of $16 \mathrm{~S}$ rRNA amplicons revealed identity index $100 \%$ with $M$. terrae and $M$. engbaekii. All DNA sequences of IS901 showed identity index ranging from 98 to $100 \%$ and 89 to $94 \%$ query coverage with $M$. avium isolates in NCBI GenBank.

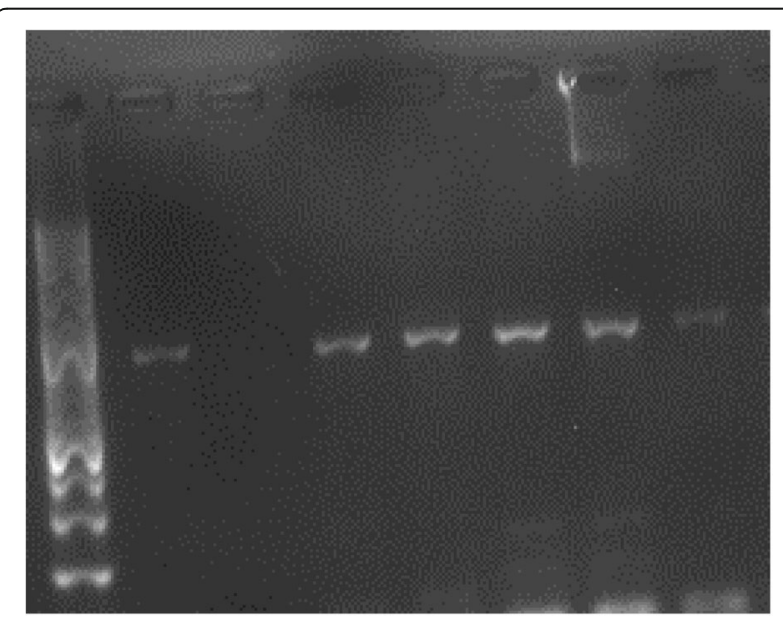

Fig. 3 Agarose electrophoresis of PCR (IS901) product of Mycobacterium avium detected from a batch of five DNA samples extracted from avian feces. M, 100 bp size molecular DNA marker; C+ positive control; C- negative control; 1 to 5 bp-753 


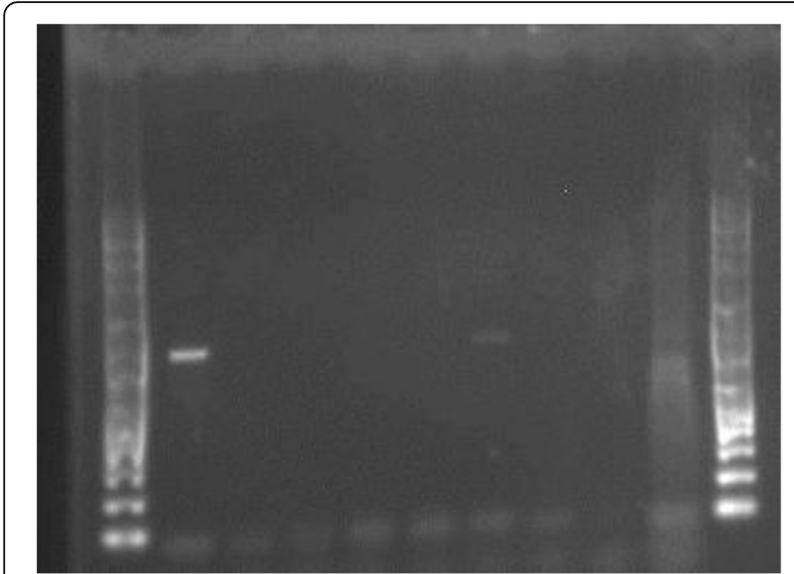

Fig. 4 Agarose electrophoresis of PCR (IS901) product of Mycobacterium avium isolated from a batch of seven DNA samples extracted from avian feces. M, 100 bp size molecular DNA marker; C+ positive control; C- negative control; line 4 (4th sample) was positive from a Black hornbill (Anthracoceros malayanus) and other fecal samples were negative

\section{Phylogenetic analysis}

Phylogenetic analysis revealed that all $M$. avium isolates separated into three main groups and each group was further divided into sub groups. The sub groups were (1) RCAD 0278 and JD88/118 strains, (2) isolates of this study, (3) FM991903 ORF, (4) M. avium huminissius, (5) M. avium huminissius, and (6) RCAD 0278 strain. DNA sequences of the current study were grouped in one sub group with $M$. avium strain RCAD 0278_1. Reconstruction of the Phylogenetic tree was supported with bootstrap values ranging from 63 to $100 \%$ (Fig. 6). Average evolutionary divergence over sequence pairs within the groups revealed that the number of base substitutions per site from averaging over all sequence pairs within sequences of the current study $(P=0.01)$ and isolates of
M. avium JD $88 / 188(P=0.001)$ were significant. On the other hand, estimates of evolutionary divergence over sequence pairs between groups showed that the number of base substitutions per site from averaging over all sequence pairs between isolates of the current study and isolates of $M$. avium JD88/188 $(\mathrm{P}=0.01)$ and $M$. avium ORF1 $(P=0.003)$ was significant. Evolutionary divergence between the sequence pairs of the isolates of the current study and M. avium RCAD02781 $(P=0.5)$ and isolates of $M$. avium huminissius $(P=0.4)$ were not significant.

\section{Discussion}

The results of this study showed that MAA $0.03 \%$ (1/ $296)$ and $2.5 \%(6 / 242)$ were detected by culture and PCR, respectively. Other environmental mycobacteria $1.7 \%(5 / 296)$ detected by culture were endemic in the birds from Selangor, Melaka, Kuala Lumpur and Putrajaya in Peninsular Malaysia. This study showed that water $(P=0.07)$ and food $(P=0.09)$ were not significant risk factors for $M$. avium and other mycobacteria infection in these birds. However, previous studies have shown that water from different sources (rivers, dams, ponds, lakes, kitchen sediments and bath rooms) is the main reservoir for nontuberculous mycobacteria [31]. In this study, majority of the birds infected with MAA comprised of captive birds as they are more susceptible to MAA mainly due to their relatively long lifespan which increases the accumulated risk of exposure and long incubation period of the pathogen [2,3]. Although, access of wild birds to the premises of the chickens and birds was not significant risk factor $(P=0.1)$, previous studies have shown that wild birds play important role in the dispersion of pathogens including MAA [34, 35]. Furthermore, the risk analysis may be underestimated due to sample size, low incidence rate and low sensitivity

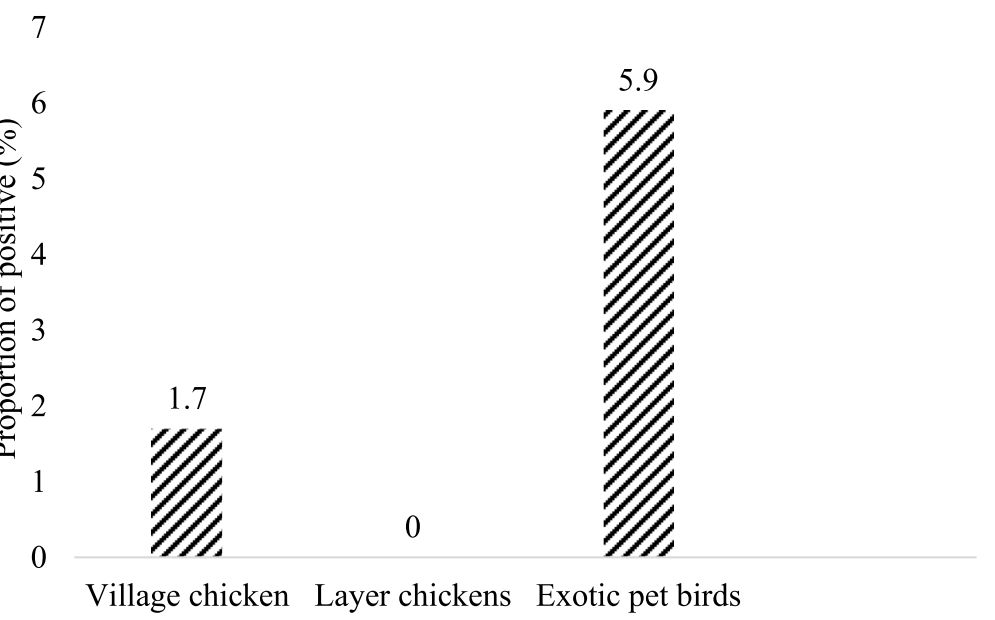

Fig. 5 Mycobacterium avium subsp. avium detected by PCR IS901 from avian fecal samples 
Table 2 Analysis of risk factors using PCR as dependent variable

\begin{tabular}{|c|c|c|c|c|c|}
\hline Factor & Categories & Prevalence (\%) & $P$-value & OR & $95 \% \mathrm{Cl}$ \\
\hline \multirow[t]{4}{*}{ Location } & $\mathrm{F} 4^{*}$ & $1 / 11(9)$ & & 1.0 & Ref \\
\hline & $\mathrm{F} 13^{\#}$ & $2 / 11(18.2)$ & 0.5 & 0.450 & $0.035-5.843$ \\
\hline & $\mathrm{F} 14^{\#}$ & $2 / 12(20)$ & 0.5 & 0.5 & $0.039-6.43 \mathrm{~s}$ \\
\hline & $\mathrm{F} 15^{\#}$ & $1 / 21(4.7)$ & 0.5 & 2.0 & $0.113-35.41$ \\
\hline \multirow[t]{2}{*}{ No of birds } & $<50$ & $5 / 67$ & & 1.0 & Ref \\
\hline & $>500$ & $1 / 141$ & $0.01^{\mathrm{a}}$ & 11.47 & $1.313-100.3$ \\
\hline \multirow[t]{3}{*}{ Type of the birds } & Village chicken & $1 / 57$ & & 1.0 & Ref \\
\hline & Layer chicken & $0 / 100$ & - & - & NA \\
\hline & Captive pet birds & $5 / 85$ & 0.22 & .28 & $0.03-2.512$ \\
\hline \multirow[t]{2}{*}{ Breed of birds } & Local chicken & $1 / 157$ & & & Ref \\
\hline & Exotic captive birds & $5 / 85$ & $0.02^{\mathrm{a}}$ & 0.103 & $0.012-0.893$ \\
\hline \multirow[t]{2}{*}{ Feed } & Commercial & $2 / 168$ & & & Ref \\
\hline & Local & $4 / 74$ & 0.07 & 0.21 & $0.038-1.178$ \\
\hline \multirow[t]{2}{*}{ Source of water } & Open surface tank & $4 / 80$ & & & Ref \\
\hline & Drinkers & $2 / 162$ & 0.09 & 4.21 & $0.75-23.495$ \\
\hline \multirow[t]{3}{*}{ Hygiene } & Good & $3 / 131$ & & & Ref \\
\hline & Fair & $3 / 71$ & 0.35 & 0.531 & $0.104-2.704$ \\
\hline & Poor & $0 / 40$ & & & \\
\hline \multirow[t]{2}{*}{ Access of wild birds } & Yes & $5 / 122$ & & & Ref \\
\hline & No & $1 / 120$ & 0.1 & 5.08 & $0.585-44.191$ \\
\hline
\end{tabular}

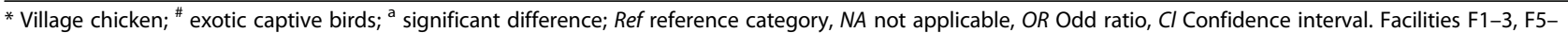
12 and F16-19 were not included in the analysis as there was zero prevalence in the facilities

of the current testing methodologies to detect mycobacteria from infected birds.

The laboratory tests used in this study showed some agreement with previous reported studies $[22,36]$. Z-N test was not optimal to detect all MAA by culture and PCR. Although the smears were prepared from concentrated pellet sediments, it did not improve the sensitivity of microscopy results. Since that the sensitivity of microscopy is around $10^{4} \mathrm{CFU} / \mathrm{ml}$ [35], the negative results for microscopy allow us to estimate that the concentration of AFB in the avian fecal samples could be less than $10^{4} \mathrm{CFU} / \mathrm{g}$ of feces. Results of the current study are in line with other studies that reported a low sensitivity of microscopy from duodenal aspirates (5.8\%) [37] and fecal samples from Japanese quails (7.2\%) [22].

Culture method could detect $2.0 \%$ (6/296) of mycobacteria identified as $M$. avium, $M$. terrae, $M$. engbaekii and three other isolates as Mycobacterium spp. Although the recovery of mycobacteria on L-J culture was very low, we postulate that this low isolation rate may reflect the real occurrence of mycobacteria in chickens and birds. Furthermore, CPC-VNA decontamination method may has a favorable impact on culture sensitivity by reducing the contamination rate $[14,23-25,36]$ and increasing the number of positive AFB culture. Isolation of environmental mycobacteria like $M$. avium, $M$. terrae and $M$. engbaekii, which do not possess IS901, may not be pathogenic to the birds because no clinical relevance of these species have been reported [38]. However, isolation of such species of mycobacteria in this study shows that CPC-VNA method allows the isolation of other mycobacteria. Regarding the contamination rate, this study reported that the sample collection procedure and immediate process of the samples had effect on the contamination rate. Fecal cultures from captive birds, in which feces were collected with minimal contamination showed less contamination than cultures from village chicken and layer chicken feces. High proportion of contaminated cultures from the village chickens and layer chickens shows the implications of sample collection procedure as well as immediate process of the samples. Village chickens were free in the fenced area or around the house buildings, therefore sample collection procedure with minimal contamination adopted for this study was not applicable to village chickens. Majority of the samples from village chickens were collected after feces were deposited on ground. Hence, contamination rate was high in the cultures from village chicken. Samples from layer chickens were collected aseptically as they were kept in cages. However, samples that were not processed on the same day of sample collection due to logistic issues (e.g., transportation). Samples from layer 


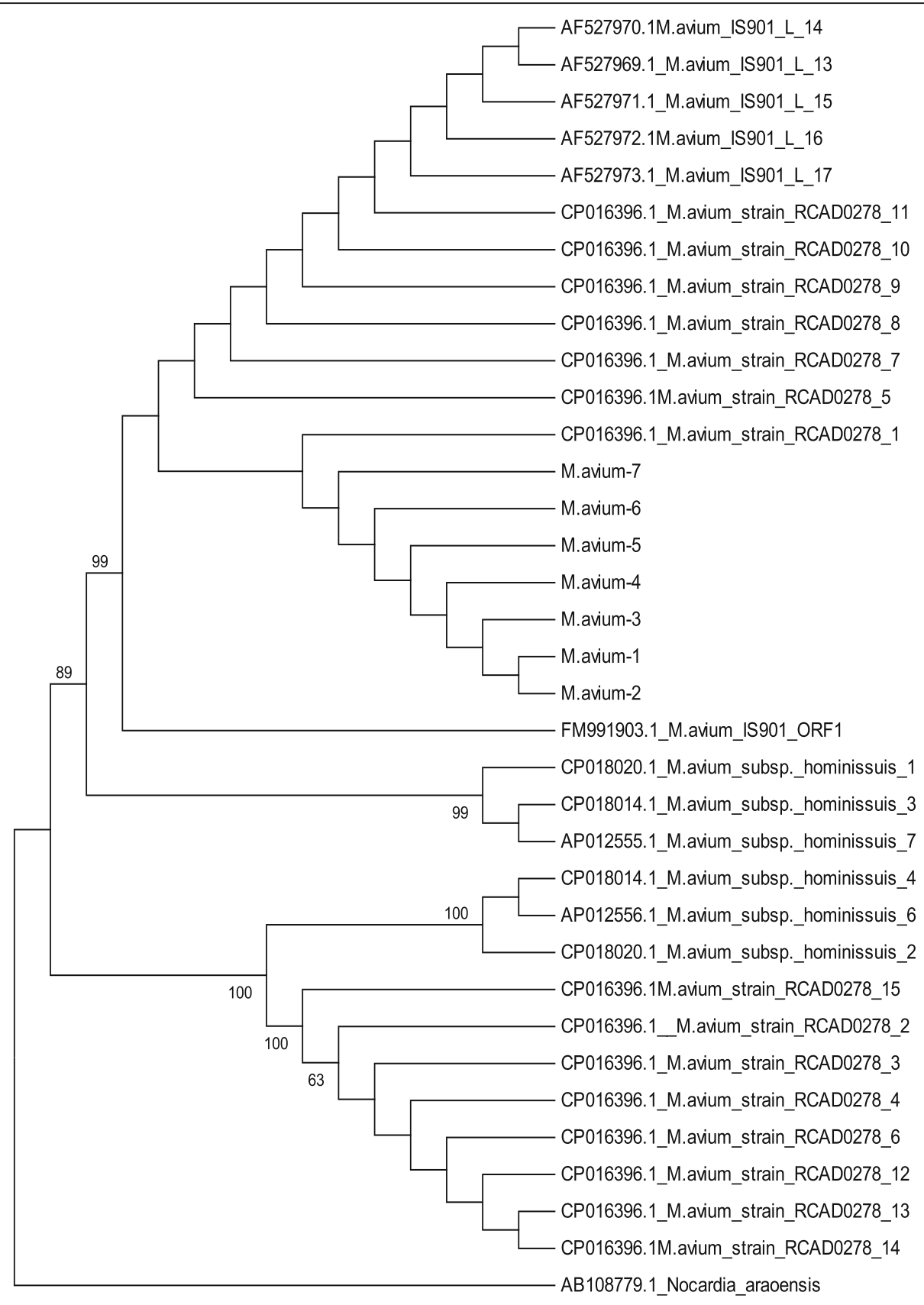

Fig. 6 A maximum likelihood phylogentic tree showing the relation between strains of Mycobacterium avium (IS901 gene). Phylogenetic analysis was performed using Mega6. The analysis was carried out based on IS901 nucleotide sequences. Analysis showed that DNA sequences of $M$. avium strains obtained in this study were closely related to each other and to M. avium strain RCAD0278. The starins of M. avium RCAD0278, M. avium cervine strain JD/88, M. avium ORF1 and M. avium huminsiuss from human were grouped in separate clusters. ${ }^{a}$ Significant evolutionary divergence within the group, ${ }^{b}$ significant evolutionary divergence between $M$. avium isolated in this study and isolates of $M$. avium retrieved from Genbank. ${ }^{c}$ Evolutionary divergence within and between the groups was not significant

chickens were stored at $-20^{\circ} \mathrm{C}$ for 1 week before being processed. Previous studies have shown that time for samples processing is important factor affecting primary isolation of mycobacteria [18]. Given that our previous study [24] reported that CPC-VNA can control the contamination rate of L-J cultures better than other methods, we postulate that the contamination rate $(27.9 \%)$ of L-J cultures in this study is acceptable.

Regarding the use of PCR IS901 as a rapid method to detect MAA than using culture [14, 38], this study reported that $2.5 \%(6 / 242)$ of MAA DNA from fecal samples was detected by PCR IS901. Likewise, other authors 
such as Kriz et al. [14] detected MAA from intestine and fecal samples of domestic fowl and other birds only by PCR, but not culture. In this study, the rapid detection of MAA by PCR IS90 is an advantage in order to taking actions of prevention of dissemination and transmission of mycobacteria [39]. Likewise, the current study showed that sequencing of amplified fragment is an affordable potential tool for species identification of mycobacteria [40].

Differences in the detection of MAA by using culture, and further speciation by PCR (16S rRNA), against direct detection of MAA using PCR (IS901), can be explained by the difference between sensitivity of the culture and PCR. High sensitivity of PCR can be explained by its ability to detect DNA from viable as well as from dead organism [32] unlike culture that only detect viable organisms. In that way, the toxic effect of CPC-VNA method is a variable that has a negative effect on the sensitivity of culture to detect viable organisms $[25,27]$. Other authors have also reported differences in the detection of MAC by culture and PCR. Kriz and coworkers [14] detected M. avium subsp. avium in tissue samples of $80 \%$ Cochin hen, in intestine and fecal samples of $60 \%$ of hens and, $20 \%$ of the raptors (feces) by PCR using IS901 gene unlike culture samples that were negative. In another study, Klanicova et al. [30] detected three sub species of M. avium in raw and processed meat by PCR using IS901 and IS1245 genes. However, cultures of these meat samples were negative for mycobacteria. Douarre et al. [32] also reported that PCR IS900 detected (36.2\%) M. avium subsp. paratuberculosis in bovine feces, while only $7.9 \%$ PCR positive samples were culture positive. Keeping in view the findings of the current study as well as previous studies [14, 30, 32], PCR can be used as a rapid alternate to culture for diagnosis of slow growing mycobacteria [41]; however, this test cannot exclude LJ culture as it is considered gold standard to detect viable organisms (19).

Another interestingly finding reported in this study is the detection of MAA from the fecal sample of White Pelican (Pelecanus onocrotalus) sample using culture and Black Hornbill (Anthracoceros malayanus) using direct PCR. Although MAA has been reported in domestic hen [42], macaw [16, 43], cockatoo [16, 43], and commercial ducks [1] from different region of the world, to the best of our knowledge only one study [43] reported MAA from White Pelican but there is no published data from Black Hornbill.

Among some limitations of the study was that the infection of the birds with $M$. avium and other species of mycobacteria should be confirmed by postmortem and histopathology [17], however, in the current study, postmortem and histopathology could not be performed. Another limitation was the quantity of feces and procedure for collection of fecal samples. One gram of feces was required for culture and $200 \mathrm{mg}$ for DNA extraction. However, the required quantity of feces from all village chicken (free range) and exotic captive birds could not be collected. Village chickens were free, deposited feces on ground which were exposed to environment, therefore a larger portion of feces discarded. On the other hand, feces of the small pet birds is normally small in quantity. Other limitations that had effect on the sample size were the limited availability of chickens older than one year and exotic captive birds so a total of 300 birds were sampled rather than the calculated sample size of 382. Convenient sampling methods were adopted for selection of farms (bird facilities) due to logistic difficulties. Therefore, occurrence of MAA may be underestimated due to sample type and small sample size. Nevertheless, this preliminary study with limited resources with small sample size reports the occurrence of $M$. avium and other environmental mycobacteria in chicken and captive pet birds in Peninsular Malaysia. Moreover, since Peninsular Malaysia is large country and chicken and captive birds were conveniently sampled from small number of locations which may not be representative of the whole country. Future studies must include a large study area with larger sample size so as the result can be extrapolated to whole population. Furthermore, another limitation of the current study is that causal effect of the identified risk factors cannot be estimated because the cross sectional design of the study which does not allow to determine the temporal sequence of the cause and effect of the risk factors (33).

\section{Conclusion}

This study reports the occurrence of MAA in chickens and birds in the selected areas of Peninsular Malaysia and encourages further studies that include a higher number of birds from same and other locations in Malaysia. The culture of avian feces decontaminated by CPC-VNA method and the direct detection of MAA DNA from fecal samples by PCR IS901 should be considered as referential tests for the detection of MAA and other members of the genus Mycobacterium in further studies.

\section{Methods \\ Reagents}

Preparation of CPC, VNA antibiotic cocktail, and L-J culture were described previously [24]. Briefly, CPC (1\%) solution was prepared by adding $5 \mathrm{~g}$ of CPC (Merck, Germany) and $10 \mathrm{~g}$ of $\mathrm{NaCl}$ (Merck, Germany) in 500 $\mathrm{mL}$ distilled water. VNA working solution consisted of VAN $(100 \mu \mathrm{g} / \mathrm{ml})$, NAL $(100 \mu \mathrm{g} / \mathrm{ml})$ and AMB $(50 \mu \mathrm{g} /$ $\mathrm{ml})$. L-J culture was prepared according to the manufacturer's instruction (HiMedia, India). 


\section{Sample size}

Expected prevalence of avian mycobacteriosis was taken as $50 \%$ [35] as there is no previous study on the prevalence of disease in the birds in Peninsular Malaysia. Following formula was used to calculate the required sample size $(N)$ [44].

$$
\mathrm{N}=\frac{1.96^{2} P_{\exp }\left(1-P_{\exp }\right)}{d^{2}}
$$

where $N=$ required sample size. Pexp = expected prevalence, $\mathrm{d}=$ desired absolute precision.

Using the above formula, the estimated sample size was 384 fecal samples. However, due to limitations in sample collection, the sample size was reduced to 300 which included village chicken Gallus domesticus ( $n=$ $100)$, layer chicken $(n=100)$ and captive birds $(n=100)$. Exotic captive birds included macaw Ara spp. $(n=13)$, cockatoo Cacatua spp. $(n=14)$, African grey parrot Psittacus erithacus $(n=23)$, amazon parrot Amazona spp. $(n=8)$, Parakeet Melopsittacus undulates $(n=4)$, Blue fronted parakeet Thectocercus acuticaudatus $(n=1)$, Lori keets Phigys solitaries $(n=7)$, Parakeet rosella Platycercus $(n=1)$, pigeon Columbia domestica $(n=10)$, Cocktiel Nymphicus hollandicus $(n=2)$, Indian ring neck parrot Psittacula krameri $(n=1)$, Sunconure Aratinga solstitialis $(n=2)$, Green cheek parrot Pyrrhura molinae $(n=1)$, Monk parakeet Myiopsitta monachus $(n=1)$, White pelican Pelecanus onocrotalus $(n=5)$, Curassow Mitu mitu $(n=1)$, Black Hornbill Anthracoceros malayanus $(n=2)$, Pea hen Pavo cristatus $(n=1)$, White Bellied Sea Eagle Haliaeetus leucogaster $(n=2)$ and Buffy fish owl Ketupa ketupu $(n=1)$. Convenient sampling procedure was adopted for selection of poultry farms as well as the birds. Location of the farm, type and number of birds are summarized in Table 3.

\section{Study area}

The study was conducted in the central region of Peninsular Malaysia (Selangor and Melaka states and Federal Territories of Kuala Lumpur and Putrajaya) (Table 3 \& Fig. 7). Kuala Lumpur is the national capital and Putrajaya is the federal administrative center of Malaysia. Selangor state is located on the west coast of Peninsular Malaysia. While Melaka state is located in the southern region [45].

\section{Sample collection}

Fecal samples were collected from May 2016 to September 2017. Fecal samples were collected during morning hours. For sample collection with minimal contamination, clean newspapers were spread beneath the cages. Feces were collected in sterilized Falcon tube $50 \mathrm{~mL}$ (TPP ${ }^{\oplus}$, Switzerland) using sterilized metal spatula. An insulated container with ice packs was used to keep the samples cool during transportation to the laboratory. Samples were aliquoted into two, one for microbiology and other for direct PCR detection. However, very small samples were either used for culture or PCR. Sample aliquots for PCR were stored at $-20^{\circ} \mathrm{C}$ and samples for microbiology were processed on the same day otherwise stored at $4{ }^{\circ} \mathrm{C}$ for not more than $24 \mathrm{~h}$. However, fecal samples from layers were collected by veterinarian at layer farm and were stored at $-20^{\circ} \mathrm{C}$ for one week and transported to the laboratory. Farms were categorized into four groups according to the number of birds, the categories were as <50, 50 to 100,100 to 200 and $>500$.

\section{Isolation of mycobacteria Preparation of fecal samples}

One (1) g of fecal sample was homogenized in $30 \mathrm{~mL}$ sterile distilled water in a $50 \mathrm{~mL}$ Falcon tube. However, some of the samples which were too small in quantity, less than one gram feces was used. Sample homogenization was performed with vigorous shaking followed by vortex at high speed for $1 \mathrm{~min}$. Then the samples were allowed to stand undisturbed at room temperature for $30 \mathrm{~min}$. Supernatants were filtered through sterile surgical gauze (mesh size $19 \times 15$ Promedictech Sdn Bhd, Malaysia). Filtrates were centrifuged at 3000×g (Eppendorf AG-22331 Hamburg, Germany) at $10{ }^{\circ} \mathrm{C}$ for $20 \mathrm{~min}$. Supernatants were poured off and pellets were resuspended in $1 \mathrm{~mL}$ sterile distilled water and mixed well by short vortex. A $100 \mu \mathrm{L}$ of pellet sediment was used for AFB smear and remaining pellet sediment was subjected to decontamination with CPC.

\section{AFB smear preparation}

A $100 \mu \mathrm{L}$ of the concentrated fecal sample (pellet sediment) was placed and spread onto a clean glass slide, allowed to air dry, heat fixed and stained with Ziehl Neelsen (Z-N) stain. Smears were examined under 100X oil immersion magnification.

\section{Decontamination}

Remained pellet sediment was mixed with $25 \mathrm{~mL}$ of CPC (1\%) by vigorous shaking and vortex. Then the suspension was allowed to stand at $37^{\circ} \mathrm{C}$ for $24 \mathrm{~h}$. The suspension was centrifuged at $3000 \times \mathrm{g}$ for $15 \mathrm{~min}$ at $10^{\circ} \mathrm{C}$ and supernatants were decanted and pellets were dissolved in $1 \mathrm{~mL}$ of sterile distilled water before mixing with equal volume of VNA working solution and incubated at $37^{\circ} \mathrm{C}$ for $24 \mathrm{~h}$. Sediments were mixed by vigorous shaking before inoculating in triplicate onto L-J slants with $100 \mu \mathrm{L}$ of pellet sediment. Each replicate was considered as an individual culture. L-J slants were placed in a slanted position and incubated at $37^{\circ} \mathrm{C}$ for no more than 8 weeks. Mycobacterial colonies were 
Table 3 Location, number and description of chickens and birds

\begin{tabular}{|c|c|c|c|c|}
\hline Farm ID & Location & Description & Type of Birds & No of samples \\
\hline F1 & Selangor & Village chicken & Village chicken & 4 \\
\hline F2 & Selangor & Backyard chicken & Village chicken & 29 \\
\hline F3 & Selangor & Chicken farm & Village chicken & 12 \\
\hline F4 & Selangor & Chicken farm & Village chicken & 12 \\
\hline F5 & Selangor & Chicken farm & Village chicken & 23 \\
\hline F6 & Selangor & Chicken farm & Village chicken & 4 \\
\hline F7 & Selangor & Chicken farm & Village chicken & 16 \\
\hline F8 & Melaka & Layer farm & Layer chicken & 11 \\
\hline F9 & Melaka & Layer farm & Layer chicken & 11 \\
\hline F10 & Melaka & Layer farm & Layer chicken & 35 \\
\hline F11 & Melaka & Layer farm & Layer chicken & 43 \\
\hline F12 & Putrajaya & Wetland park & Exotic birds & 5 \\
\hline F13 & Selangor & Private Zoo & Exotic birds & 12 \\
\hline F14 & Kuala Lumpur & Zoo Negara & Exotic birds & 15 \\
\hline F15 & Klang & Pet shop & Exotic birds & 21 \\
\hline F16 & Selangor & Indoor birds & Exotic Birds & 8 \\
\hline F17 & Putrajaya & Private owner & Exotic Birds & 3 \\
\hline F18 & Selangor & Private owner & Exotic Birds & 11 \\
\hline F19 & Selangor & Private owner & Exotic Birds & 25 \\
\hline Total & & & & 300 \\
\hline
\end{tabular}

confirmed by Z-N staining followed by PCR amplification of 16S rRNA and IS901 genes.

\section{Identification of mycobacteria DNA extraction from isolates}

DNA extraction was performed using Blood and tissue kit (Qiagen ${ }^{\circ}$ ) as described previously [24] . Briefly, fresh colonies were lysed in $200 \mu \mathrm{L}$ lysis buffer incubated at $37^{\circ} \mathrm{C}$ for $30 \mathrm{~min}$ (heat block-Labnet, USA). To digest the contaminating proteins and lyse all cells, $20 \mu \mathrm{L}$ proteinase $\mathrm{K}$ and $200 \mu \mathrm{L}$ buffer $\mathrm{AL}$ were added to the mixture and incubated for $10 \mathrm{~min}$ at $70^{\circ} \mathrm{C}$ which was followed by precipitation of nucleic acid using $200 \mu \mathrm{L}$ of ethanol $96 \%$ (Fisher Scientific, UK). After applying all lysate of each sample to a DNeasy Mini column and centrifugation for $1 \mathrm{~min}$ at $5900 \times \mathrm{g}$ (Profuge $14 \mathrm{D}$, USA), the DNA was washed with $500 \mu \mathrm{L}$ of buffers AW1 and AW2. DNA was eluted with $50 \mu \mathrm{L}$ Buffer AE. The quality of DNA was assessed by gel electrophoresis using $0.8 \%$ agarose gel. Purified DNA was stored at $-20^{\circ} \mathrm{C}$.

\section{PCR amplification}

Top $\operatorname{Taq}^{\text {TM }}$ Master Mix (Qiagen ${ }^{\circ}$ ) was used to perform amplification of purified DNA following the manufacturer's instruction. Briefly, a $25 \mu \mathrm{L}$ reaction mixture was prepared by adding $12.5 \mu \mathrm{L}$ Top Taq Master Mix $2 \mathrm{x}$, $6.5 \mu \mathrm{L}$ RNase free water, $5 \mu \mathrm{L}$ template DNA and $0.5 \mu \mathrm{L}$ $(0.2 \mu \mathrm{M})$ of each primer. A $564 \mathrm{bp}$ fragment of $16 \mathrm{~S}$ rRNA was amplified by $16 \mathrm{MycF} 55^{\prime}$-CGT GCT TAA CAC ATG CAA GTC G-3' and 16MycR 5' - GTG AGA TTT CAC GAA CAA CGC-3 [24]. Initially DNA was denatured for $2 \mathrm{~min}$ at $95^{\circ} \mathrm{C}$ followed by 35 cycles of denaturation at $94{ }^{\circ} \mathrm{C}$ for $30 \mathrm{~s}$, annealing at $52{ }^{\circ} \mathrm{C}$ for $30 \mathrm{~s}$ and extension at $72{ }^{\circ} \mathrm{C}$ for $1 \mathrm{~min}$. Final extension was performed for $10 \mathrm{~min}$ at $72^{\circ} \mathrm{C}$ [24]. Eppendorf Mastercycler (Germany) was used for amplification of DNA. Primer set; IS901-F 5'-GAA CGC TGC TCT AAG GAC CTG TTG G-3' and IS901-R 5' - GGA AGG GTG ATT ATC TGG CCT GC-3' was used to amplify a $753 \mathrm{bp}$ fragment of IS901 to identify M. avium [24]. Reaction mixture and concentrations were similar as described for $16 \mathrm{~S}$ rRNA. Amplification conditions included initial denaturation for $3 \mathrm{~min}$ at $95^{\circ} \mathrm{C}$ and 35 cycles of denaturation for $1 \mathrm{~min}$ at $95^{\circ} \mathrm{C}$, annealing for $40 \mathrm{~s}$ at $60^{\circ} \mathrm{C}$, extension for $35 \mathrm{~s}$ at $72^{\circ} \mathrm{C}$. Final extension was carried out for $10 \mathrm{~min}$ at $72^{\circ} \mathrm{C}$ [24]. PCR amplification was performed in thermocycler (BIO RAD, USA). Mycobacterium avium sub species avium (ATCC 15769) and RNase free water $\left(\right.$ Qiagen $\left.^{\circ}\right)$ were included as positive and negative controls in each run of PCR assays. 


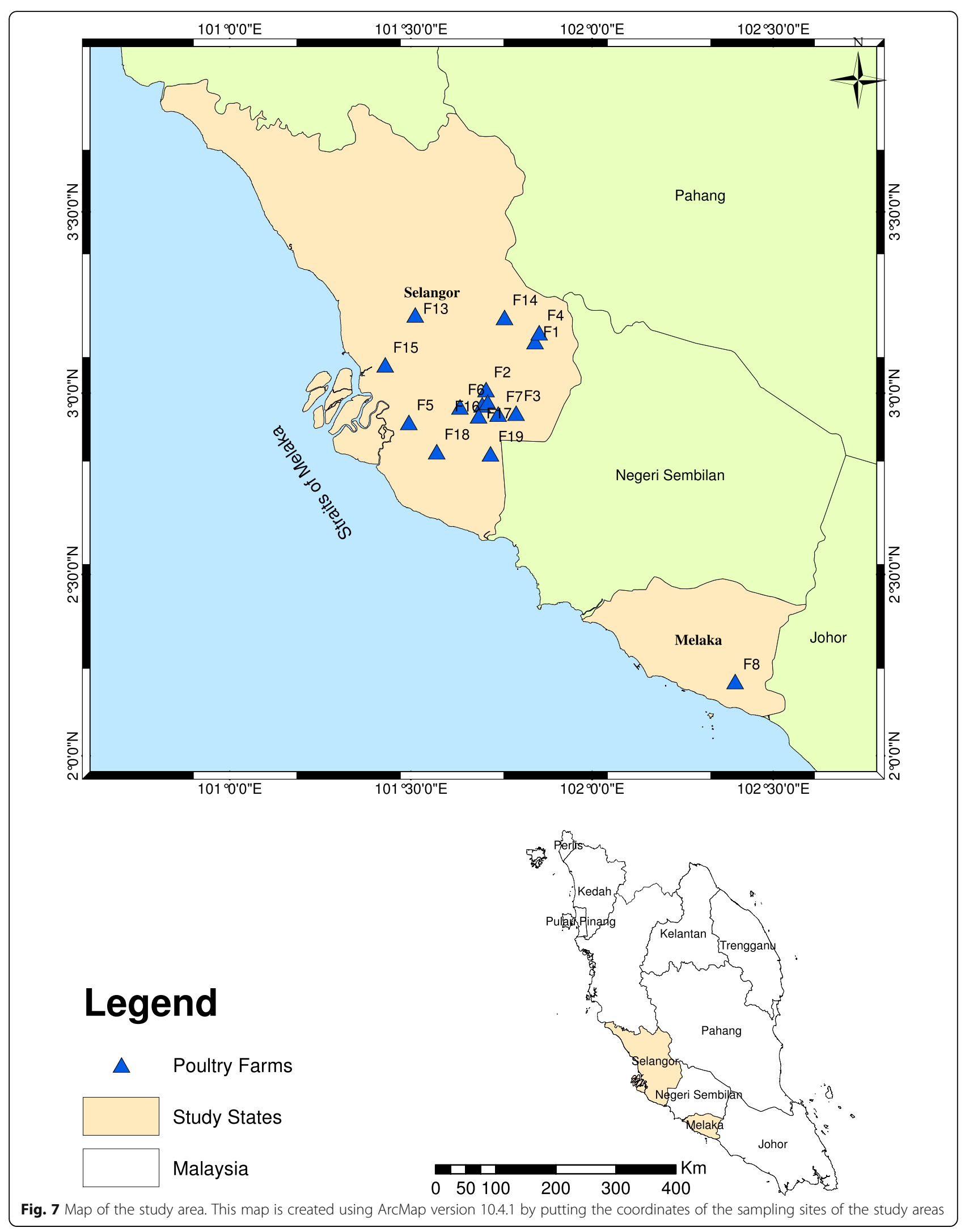




\section{Detection of $M$. avium DNA in the feces DNA extraction}

DNA was extracted from fresh or frozen fecal samples using QIAamp ${ }^{\circ}$ Fast DNA Stool Mini Kit (Qiagen ${ }^{\circ}$ ) according to the manufacturer's instructions. Briefly, 220 $\mathrm{mg}$ of fecal sample was homogenized in $1 \mathrm{~mL}$ InhibitEX Buffer, incubated for $5 \mathrm{~min}$ at $90^{\circ} \mathrm{C}$ on a heating block and centrifuged for $1 \mathrm{~min}$ at $15600 \times \mathrm{g}$. A $600 \mu \mathrm{L}$ of the supernatant was transferred to a new tube containing $25 \mu \mathrm{L}$ of proteinase $\mathrm{K}$ and then $600 \mu \mathrm{L}$ of buffer AL was added, mixed by short vortex and incubated for $10 \mathrm{~min}$ at $70{ }^{\circ} \mathrm{C}$. After adding $600 \mu \mathrm{L}$ ethanol (96\%) to the lysate and mixing by short vortex, $600 \mu \mathrm{L}$ of lysate was transferred to QIAamp spin column and centrifuged for 1 min at $15600 \times$ g. All lysate was loaded to QIAamp spin column gradually by repeated transfer of lysate and centrifugation. The extract was washed twice with washing buffers AW1 and AW2 and finally DNA was eluded with $50 \mu \mathrm{L}$ Buffer ATE as described earlier.

\section{PCR amplification}

Mycobacterium avium subsp. avium was detected in feces extract DNA by amplifying a $753 \mathrm{bp}$ segment of IS901. Primers, reaction mixture, reagents concentration and thermal protocol were same as described earlier.

\section{Gel electrophoresis}

PCR products were electrophoresed in $2 \%$ agarose ( $\mathrm{Fi}$ scher Scientific, USA) in 0.5X TBE (Sigma-Alorich, Germany) stained with SYBER safe DNA gel stain (Invitrogen, USA). Gel electrophoresis was performed at $80 \mathrm{~V}$ for $90 \mathrm{~min}$. AlphaImager ${ }^{\mathrm{ma}}$ (alpha Innotech) was used to visualize the gels [24].

\section{Sequencing and sequence analysis}

PCR amplicons of 16S rRNA and IS901 were sent to First BASE Laboratories (Malaysia) for sequencing using the same primers as used for DNA amplification. Sequence data were compared by BLAST tool P analysis with bacterial sequences publically available on NCBI GenBank. Percentage of similarity with the reference sequences and query coverage were recorded. Multiple Sequence Alignment was performed using BioEdit version 7.2.5. Mega software (Mega 6) was used to reconstruct the phylogenetic tree using Maximum Likelihood. A Nocardia asteroids sequence was used as the out group.

\section{Statistical analysis}

Data was entered in Microsoft excel V.13 and SPSS V.22 was used for data analysis. Descriptive Data was present by frequency tables and percentages. Fischer exact test was used for risk factor analysis and $p$ value $<0.5$ was considered significant.

\begin{abstract}
Abbreviations
CPC: Cetylperidinium chloride - Sodium chloride; NaCl: Sodium chloride; VAN: Vancomycin; NAL: Nalidixic acid; AMB: Amphotericin B; VNA: Mixture of vancomycin, nalidixic acid and amphotericin B; L-J: Löwenstein-Jensen; Z$\mathrm{N}$ : Ziehl Neelsen; AFB: Acid fast bacilli; MAA: Mycobacterium avium subsp. avium; IS901: Insertion sequence 901; NCBI: National Centre for Biotechnology Information; BLAST: Basic local alignment search tool; Cl: Confidence interval; OR: Odds Ratio
\end{abstract}

\section{Acknowledgments}

We thank technical staff of Bacteriology Laboratory, Faculty of Veterinary Medicine for their technical assistance, Nik Mohd Faiz Nik Mohd Azmi and Dr. Aiesha for their support during sample collection.

\section{Authors' contributions}

AS and ZZ designed the project. GRP helped in the experimental design. ZZ raised funding for the project. AS carried out all experiments and wrote the manuscript. JA helped in the sampling. SAA helped in the statistical analysis. All authors have reviewed and approved the manuscript.

\section{Funding}

This study was supported by Putra Grant no 9594500, Universiti Putra Malaysia. Abdul Sattar received a stipend during his PhD studies from Higher Education Commission Government of Pakistan. The funders had no role in the study design, in the collection, analysis and interpretation of data, in the writing the manuscript, or in the decision to submit the article for publication.

\section{Availability of data and materials}

The dataset generated and/ analyzed during the current study are available in NCBI GenBank using the accession numbers MH428008, MH333265 and $\mathrm{MH} 333264$.

\section{Ethics approval and consent to participate}

Not applicable.

This study involved isolation of Mycobacterium avium from the fecal sample which were collected from the ground without any manipulation of the birds. Therefore, ethical approval from the Institutional Animal Care and Use Committee (IACUC) is not applicable.

\section{Consent for publication}

Not applicable.

\section{Competing interests}

The authors declare that they have no competing interest.

\section{Author details}

${ }^{1}$ Faculty of Veterinary and Animal Sciences, Lasbela University of Agriculture, Water and Marine Sciences, Uthal, Balochistan 90150, Pakistan. ${ }^{2}$ Department of Pathology and Microbiology, Faculty of Veterinary Medicine, Universiti Putra Malaysia UPM, 43400 Serdang, Selangor, Malaysia. ${ }^{3}$ Institute of Bioscience, Universiti Putra Malaysia, 43400-UPM, Serdang, Selangor, Malaysia. ${ }^{4}$ Department of Clinical Studies, Faculty of Veterinary Medicine, Universiti Putra Malaysia UPM, 43400 Serdang, Selangor, Malaysia. ${ }^{5}$ Department of Electrical and Computer Engineering, University of Alberta, Edmonton T6G 2V4, Canada.

Received: 26 February 2020 Accepted: 24 November 2020

Published online: 07 January 2021

References

1. Zhu DK, Song XH, Wang JB, Zhou WS, Ou XM, Chen HX, et al. Outbreak of avian tuberculosis in commercial domestic Pekin ducks (Anas platyrhynchos domestica). Avian Dis. 2016;60:677-80 https://doi.org/10.1637/11396-021916ResNote.1.

2. Tell LA, Woods L, Cromie RL. Mycobacteriosis in birds. Rev Sci Tech. 2001;20: 180-203.

3. Fulton RM, Thoen CO. Tuberculosis. In: Saif YM, Fadly AM, Glisson JR, McDougald LR, Nolan LK, Swayne DE, editors. Diseases of Poultry; 2008. p. 940-51. 
4. Hoop RK, Böttger EC, Pfyffer GE. Etiological agents of mycobacterioses in pet birds between 1986 and 1995. J Clin Microbiol. 1996;34:991-2.

5. González M, Rodriguez-Bertos A, Gimeno I, Flores JM, Pizarro M. Outbreak of avian tuberculosis in 48-week-old commercial layer hen flock. Avian Dis. 2002;46:1055-61.

6. Jamaludin AA. Broiler industry in Peninsular Malaysia. In: Idris LH, Hassim HA, MHM N, Mazlan M, Ahmad H, Bejo MH, Idrus Z, editors. Proceeding of WPSA (Malaysia Branch) and WVPA (Malaysia Branch) Scientific Conference 2013; 2013. p. 1.

7. Department of Veterinary Services (DVS). Bilangan Ayan/itik/Unggas 2015. Peninsular Malaysia: Poultry Population, 2015; 2015.

8. Aini. Disaeses in rural family chickens in South-East Asia. In: Sonaiya EB, RDS B, Gueye EF, editors. Research and Development Options for Family Poultry. Rome: Conference on family poultry, FAO; 1999. p. 37-41.

9. Scanes CG. Contribution of poultry to quality of life and economic development in the developing world. Poult Sci. 2007;86:2289-90.

10. Abraham-Oyiguh J, Sulaiman LK, Meseko CA, Ismail S, Suleiman I, Ahmed SJ, et al. Prevalence of Newcastle disease antibodies in local chicken in federal capital territory, Abuja, Nigeria. Int Sch Res Not. 2014;2014:1-3 https://doi. org/10.1155/2014/796148.

11. Ong LP, Muniandy K, How SP, Yip L, BK SL. Salmonella isolation from poultry farms in Malaysia from 2011 to 2013. Malaysian J Vet Res. 2014;5:180-1.

12. Orsi MA, Doretto L, Camillo SCA, Reischak D, Ribeiro SAM, Ramazzoti A, et al. Prevalence of Newcastle disease virus in broiler chickens (Gallus gallus) in Brazil. Braz J Microbiol. 2010;41:349-57.

13. van den Berg TP, Eterradossi N, Toquin D, Meulemans G. Infectious bursal disease (Gumboro disease). Rev Sci Tech Off Int Epiz. 2000;19:527-43.

14. Kriz P, Kaevska M, Bartejsova I, Pavlik I. Mycobacterium avium subsp. avium found in raptors exposed to infected domestic fowl. Avian Dis. 2013;57:68892 https://doi.org/10.1637/10446-110612-Case.1.

15. Shitaye JE, Matlova L, Horvathova A, Moravkova M, Dvorska-Bartosova L, Treml F, et al. Mycobacterium avium subsp. avium distribution studied in a naturally infected hen flock and in the environment by culture, serotyping and IS901 RFLP methods. Vet Microbiol. 2008;127:155-64.

16. Witte $\mathrm{CL}$, Hungerford LL, Papendick R, Stalis $\mathrm{HH}$, Rideout BA. Investigation of characteristics and factors associated with avian mycobacteriosis in zoo birds. J Vet Diagnostic Investig. 2008;20:186-96 https://doi.org/10.1177/ 104063870802000207.

17. OIE. Avian tuberculosis: version adopted by the world assembly of delegates of the OIE in May 2014. Man Diagn Tests Vaccines Terr Anim. 2017;2014 http://www.oie.int/en/international-standard-setting/terrestrialmanual/access-online/.

18. Whittington RJ. Factors affecting isolation and identification of Mycobacterium avium subsp. paratuberculosis from fecal and tissue samples in a liquid culture system. J Clin Microbiol. 2009;47:614-22 https://doi.org/ 10.1128/JCM.01986-08.

19. Aziz M, Ryszewska K, Blanc L, Vincent V, Getahun H, Wright A, et al. Expanding culture and drug susceptibility testing capacity in tuberculosis diagnostic services: the new challenge. Int J Tuberc Lung Dis. 2007;11:247-50.

20. Sockett DC, Carr DJ, Collins MT. Evaluation of conventional and radiometric fecal culture and a commercial DNA probe for diagnosis of Mycobacterium paratuberculosis infections in cattle. Can J Vet Res. 1992;56:148-53.

21. Siddiqi SH, Gerdes S. MGIT procedure mannual. In: BACTEC MGIT 960 TB System. Sparks: Bect Dickinson; 2006.

22. Tell LA, Foley J, Needham ML, Walker RL. Diagnosis of avian mycobacteriosis: comparison of culture, acid-fast stains, and polymerase chain reaction for the identification of Mycobacterium avium in experimentally inoculated Japanese quail (Coturnix coturnix japonica). Avian Dis. 2003:47:444-52.

23. Ambrosio SR, Oliveira EMDD, Rodriguez CAR, Neto JSF, Amaku M. Comparison of three decontamination methods for Mycobacterium bovis isolation. Braz J Microbiol. 2008;39:241-4.

24. Sattar A, Zakaria Z, Abu J, Aziz SA, Gabriel R. Evaluation of six decontamination procedures for isolation of Mycobacterium avium complex from avian feces. PLoS One. 2018:1-16.

25. Corner LA, Trajstman AC, Lund K. Determination of the optimum concentration of decontaminants for the primary isolation of Mycobacterium bovis. N Z Vet J. 1995:43:129-33.

26. Radomski N, Cambau E, Moulin L, Haenn S, Moilleron R, Lucas FS. Comparison of culture methods for isolation of nontuberculous mycobacteria from surface waters. Appl Environ Microbiol. 2010;76:3514-20.
27. Smithwick RW, Stratigos CB, David HL. Use of cetylpyridinium chloride and sodium chloride for the decontamination of sputum specimens that are transported to the laboratory for the isolation of Mycobacterium tuberculosis. J Clin Microbiol. 1975;1:411-3.

28. Sevilla IA, Molina E, Tello M, Elguezabal N, Juste RA, Garrido JM. Detection of mycobacteria by culture and DNA-based methods in animal-derived food products purchased at Spanish supermarkets. Front Microbiol. 2017:1-10.

29. Khare S, Ficht TA, Santos RL, Romano J, Ficht AR, Zhang S, et al. Rapid and sensitive detection of Mycobacterium avium subsp. paratuberculosis in bovine milk and feces by a combination of immunmagnetic bead separation-conventional PCR and real-time PCR. J Clin Microbiol. 2004;42: 1075-81.

30. Klanicova B, Slana I, Vondruskova H, Kaevska M, Pavlik I. Real-time quantitative PCR detection of Mycobacterium avium subspecies in meat products. J Food Prot. 2011;74:636-40 https://doi.org/10.4315/0362-028X. JFP-10-332.

31. Klanicova B, Seda J, Slana I, Slany M, Pavlik I. The tracing of mycobacteria in drinking water supply systems by culture, conventional, and real time PCRs. Curr Microbiol. 2013;67:725-31 https://doi.org/10.1007/s00284-013-0427-1.

32. Douarre PE, Cashman W, Buckley J, Coffey A, O'Mahony JM. Isolation and detection of Mycobacterium avium subsp. paratuberculosis (MAP) from cattle in Ireland using both traditional culture and molecular based methods. Gut Pathog. 2010;2:1-7.

33. Millán J, Negre N, Castellanos E, de Juan L, Mateos A, Parpal L, et al. Avian mycobacteriosis in free-living raptors in Majorca Island. Spain. Avian Pathol. 2010;39:1-6.

34. Fischer OA, Matlova L, Dvorska L, Svastova P, Pavlik I. nymphs of the oriental cockroach (Blatta orientalis) as passive vectors of causal agents of avian tuberculosis and paratuberculosis. Med Vet Entomol. 2003;17:145-50.

35. Kindu A, Getaneh G. Prevalence of avian tuberculosis in domestic chickens in selected sites of Ethiopia. J Vet Sci Technol. 2016;7:1-7.

36. Kantor IN, Kim SJ, Frieden T, Laszlo A, Luelmo F, Norval P, Rieder H, Valenzuela P, Weyer P. Loboratory services in tuberculosis control. III. Culture. Geneva, Switz: World Health Organanization; 1998.

37. Saggese MD, Tizard I, Phalen DN. Comparison of sampling methods, culture, acid-fast stain, and polymerase chain reaction assay for the diagnosis of mycobacteriosis in ring-neck doves (Streptopelia risoria). J Avian Med Surg. 2010;24:263-71.

38. Tortoli E. Microbiological features and clinical relevance of new species of the genus Mycobacterium. Clin Microbiol Rev. 2014;27:727-52.

39. Bicmen C, Gunduz AT, Coskun M, Senol G, Cirak AK, Ozsoz A. Molecular detection and identification of Mycobacterium tuberculosis complex and four clinically important nontuberculous mycobacterial species in smearnegative clinical samples by the genotype mycobacteria direct test. J Clin Microbiol. 2011:49:2874-8.

40. Ong CS, Ngeow YF, Yap SF, Tay ST. Evaluation of PCR-RFLP analysis targeting hsp65 and rpoB genes for the typing of mycobacterial isolates in Malaysia. J Med Microbiol. 2010;59:1311-6.

41. Deggim-Messmer V, Bloemberg GV, Ritter C, Voit A, Hömke R, Keller PM, et al. Diagnostic molecular Mycobacteriology in regions with low tuberculosis Endemicity: combining real-time PCR assays for detection of multiple mycobacterial pathogens with line probe assays for identification of resistance mutations. EBioMedicine. 2016;9:228-37.

42. Shitaye JE, Matlova L, Horvathova A, Moravkova M, Dvorska-Bartosova L, Trcka I, et al. Diagnostic testing of different stages of avian tuberculosis in naturally infected hens (Gallus domesticus) by the tuberculin skin and rapid agglutination tests, faecal and egg examinations. Vet Med (Praha). 2008;53: 101-10.

43. Nol P, Brannian RE, Berlowski BM, Wolcott MJ, Rocke TE. New host record of avian tuberculosis in an American white pelican; Pelecanus Erythroghynchos. Calif Fish Game. 2003;89:152-4.

44. Thrusfield M. Veterinary Epidemiology,Veterinary Clinical studies. In: Royal (Dick) School of veterinaty studies University of Edeinburgh; 2005.

45. MetMalyasia. Ministry of Science, Technology and Innovation (MOSTI) Malaysia Meteorological Department. Available on http://www.met.gov.my/. 2013

\section{Publisher's Note}

Springer Nature remains neutral with regard to jurisdictional claims in published maps and institutional affiliations. 